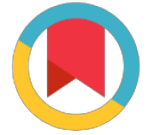

Check for updates

*For correspondence:

luyen.tranvan@gmail.com

Competing interests: The authors declare that no competing interests exist.

Received: 2017-05-10

Accepted: 2017-06-30

Published: 2017-09-05

Copyright The Author(s) 2017. This article is published with open access by BioMedPress (BMP).

This article is distributed under the terms of the Creative Commons Attribution License (CC-BY 4.0) which permits any use, distribution, and reproduction in any medium, provided the original author(s) and the source are credited.

\section{Radioisotope Enzymes And Cancer Study}

\author{
Luyen Tran
}

Vietnam Atomic Energy Commission

59 Ly Thuong Kiet, Hanoi 700012, Vietnam

\section{Abstract}

Cancer is a pathological symptom, when abnormal cells appear in certain human tissues or organs. These cells can reproduce beyond the control of normal biological protection mechanism. Because they multiply themselves rapidly, the metabolic process is accelerated, which causes an extreme need for energy, substrate material and catalyzing enzyme. Bases on these needs, we can control the metabolic process by: - Stopping the supply of energy. • Stopping the supply of substrate materials to build up the cell's structure. - Stopping the catalysis process by breaking out the enzyme's structure and/or deactivating the catalytic function of existing enzymes. - Destroying the tumor cells by extraneous agents such as radiations and chemicals. All of these methods have been studied for a long time, with a lot of resources to be spent. Although we obtained some positive result, it is nowhere closed to satisfactory. There are many reasons for this situation but the main issue is the lack of information of the processes taking place in human's cells and body. In this paper, we, however, would like to propose a method to break the structure and/or to deactivate the catalytic function of the enzyme by nuclear decay process.

\section{Keywords}

radioisotope-enzymes, metal cofactor-enzymes (M-enzymes), nuclear decay, nuclear recoil.

\section{Funding}

\section{References}

